\title{
Information and Communication Technology Adoption Strategies of Emerging Multinationals From India
}

\author{
Arindam Mondal, XLRI - Xavier School of Management, Jamshedpur, India \\ (iD) https://orcid.org/0000-0002-8890-6135 \\ Amit Baran Chakrabarti, Indian Institute of Management, Visakhapatnam, India \\ iD https://orcid.org/0000-0001-6511-5747
}

\begin{abstract}
The growth and rising prominence of multinationals from emerging markets (eMNCs) mark a significant phase in the evolution of the world economy in the last decade. This study investigates the effect of eMNCs' institutional embeddedness in terms of age on the adoption strategy of new and emerging information and communication technologies (ICT). Using panel multiple regression on a unique database of 3,756 observations from 394 Indian eMNCs in period of 2009 to 2019, the authors find that firm age has a unique negative impact on ICT investments of eMNCs. However, ownership is able to influence the negative impact of age in unique ways. Business group affiliation attenuates the impact of firm age on ICT investments, such that the reduction in ICT investments with firm age is less for BG-affiliated firms. Meanwhile, the higher the foreign institutional ownership in eMNCs, the lower the impact of firm age on ICT investments.
\end{abstract}

\section{KEYWORDS}

Business Groups, Emerging Multinationals, Foreign Institutional Investors, ICT Investments, India, Pro-Market Reforms

\section{INTRODUCTION}

Whether firms can improve performance by allocating financial resources for information and communication technology (ICT) is an important question in strategic management and information systems literature (Porter, 2001; Kohli \& Devaraj, 2003; Melville, Kraemer, \& Gurbaxani, 2004; Teece, 2007). ICT adoption has drastically modified communication, sales, and information methods (Lapierre \& Denier, 2005), thus enabling firms to achieve strong competitive advantage over its peers. Consequent to the beneficial reports of ICT adoption, few studies also started to investigate the barriers to ICT implementation (Bugamelli \& Pagano, 2004; Knockaert, Spithoven, \& Clarysse, 2010). However, much of this research focuses on traditional multinationals from the advanced world 
(aMNCs) (Fabiani et al., 2005; Hollenstein, 2004; Morgan et al., 2006), thereby leaving out the 'new' multinationals from emerging markets (eMNCs) - many of whom had effectively deployed ICT in their business processes to become successful global corporations in last two decades (Dohse, Hassink, \& Klaerding, 2012; Beerepoot \& Roodheuvel, 2016). For instance, the remarkable performance of BAT (standing for Baidu, Alibaba and Tencent), epitomizes the rapid transformation of the Chinese technology sector from mere imitator to innovator (Demirkan, Yang, \& Jiang, 2019). Such attention is warranted because eMNCs face unique institutional conditions in their home environment and have resource limitations, which can affect how substantively they adopt these new and emerging ICT technologies in their business models.

Given the limited empirical research on ICT adoption by eMNCs, our research will focus on the role of the various organizational factors on ICT adoption of eMNCs from a big and important emerging market - India. With 451 million monthly active internet users at end of financial year 2019, India is now second only to China in terms of internet users, according to a report by Internet and Mobile Association of India (Mandavia, 2019). According to Google.Inc's recent report, “On an average India adds 40 Million internet users on a Year-on-

Year basis, which is among the fastest in the world. An Indian subscriber now has an average 8GB per month mobile data usage which has reached levels of developed markets" (Agnihotri, 2019). The Indian Government, through their 'Digital India' programme has encouraged the development of digital infrastructure, improving digital literacy and increasingly providing online services to citizens, and has made it a top strategic priority, as an enabler of competitive advantage within the economy. Indian eMNCs, across sectors are focusing on digital transformations by adopting new and emerging technologies such as social media, mobility, analytics and cloud, artificial intelligence etc.

At the same time, ICT adoption requires agility and flexibility within the organization, significant resource commitments and has inherently uncertain performance consequences (Melville et al., 2004; Liang, You, \& Liu, 2010). As institutional and competitive pressures are constantly evolving in emerging markets (Hoskisson, Eden, Lau, \& Wright, 2000); not all eMNCs are in the same phase in the life cycle and embedded in their business environment (Helfat \& Peteraf, 2003). eMNCs that are less embedded, path-dependent in their business approaches can embrace these new technologies to adapt themselves to today's dynamic competitive reality. For older eMNCs, unlearning their existing 'ways of doing business' (Barkema \& Vermeulen, 1998), becomes increasingly difficult as they age, due to the increasing cognitive, political, relational barriers and organizational inertia (Autio, Sapienza, \& Almeida, 2000). This led us to enquire whether eMNC age acts as an impediment to higher investments in ICT technologies or not.

It is now well established that diversified business groups (henceforth 'BGs') play an important role in the socio-economic landscape of many emerging economies (see Khanna \& Yafeh, 2007; Carney et al., 2011, for a review). Many of these eMNCs are affiliated to the BGs (Gaur, Kumar, \& Singh, 2014). While the focus of early research on BGs was to understand the reasons for their existence, and the costs and benefits for firms affiliated to them (e.g., Khanna \& Palepu, 2000, Chacar \& Vissa, 2005), more recent work has examined the impact of BG affiliation on various firm strategic outcomes. This study therefore analysed the role of such BG affiliation on eMNCs' ICT adoption strategy. At the same time, foreign financial institutions have been very active in the Indian stock market and accelerated their investments in listed firms in the last decade. They are found to facilitate technology transfer (Chibber and Majumdar, 1999), which can particularly benefit the eMNCs in learning and adopting new and emerging ICT. This study therefore explores how foreign institutional investors influence eMNCs' willingess to adopt advance ICT technologies. As India is the second largest home to eMNCs (BCG, 2013) and it has the world's second largest internet user base (The Economic Times, 2019), the authors test their predictions using a proprietary, longitudinal panel data set of 394 Indian eMNCs featuring in the S\&P Bombay Stock Exchange (BSE) 500 index covering a ten-year period from 2009-10 to 2018-19. 
This study makes two specific contributions to the literature on eMNCs and information studies literature. Using the contextual peculiarities of emerging markets, this study investigates some of the factors responsible for catch-up in term of ICT capabilities by eMNCs, as compared to aMNCs. More specifically, the study demonstrates that embeddedness in the institutional context has an impact on the ICT adoption strategy of eMNCs. The study argues that older firms are more inertial due to their embeddedness in an institutional context characterized by protectionism and limited competition, compared to their younger counterparts, who appeared in a more liberalized era. Thus, younger firm are more motivated towards ICT investments to enhance their own competitiveness. Second, our study showcases how ownership plays a role in the ICT adoption strategy of eMNCs. With dominant market positions in emerging markets, BG affiliated eMNCs have less strategic motivation to invest in ICT technologies, whereas it is the opposite for their non-BG independent counterparts. Further, foreign institutional investors encourage eMNCs to undertake such investments. These findings enrich understating of the elements of ICT adoption strategy of eMNCs in today's digital era.

\section{THEORY AND HYPOTHESIS}

\section{eMNC Type and ICT Investments: Young Versus Old Firms}

Firm age determines how embedded a firm is in its business environment, which then determines the likelihood that it can alter its strategic direction. It also indicates the vintage of its capital and technology. Institutional theory suggests that firms gain legitimacy by following an established pattern of behaviour (DiMaggio \& Powell, 1983). The search for legitimacy reinforces these established patterns and limits exploring other strategic alternatives (Guille'n, 2002). As the firm grows older and gets bigger in size, organizational inertia tends to set in (Miller \& Chen, 1994). Over time, they get locked into a trajectory, regardless of whether it is the best strategic choice or not (Burgelman, 2002). Opening up of markets in emerging economies has exposed such eMNCs to new competitive pressures from foreign aMNCs, thereby altering the nature of competition in the home markets (Peng, 2006; Dau, 2013). Many restrictions related to trade and businesses were relaxed, accordingly, the Indian industry witnessed a period of entrepreneurial rejuvenation, wherein a number of new eMNCs sprang up to take advantage of the new opportunities (Chari \& Dixit, 2015).

In institutional environments undergoing such constant flux, eMNCs that are less embedded, less path-dependent in their business processes are more likely to change faster, in response to external pressures. Established firms have a plethora of options to build and sustain their competitive advantage (Contractor, 2013) including from brand identity (Vukasovič, 2012), supplier and distributor networks, political connections (Hillman, Zardkoohi, \& Bierman, 1999; Schuler, Rehbein, \& Cramer, 2002) etc. to name a few. The presence of these dense networks with suppliers, distributors, customers often lends older firms a strong domestic competitive position, relative to younger firms, but those dense networks simultaneously limit their capacity to change or adjust to changes in the environment (Uzzi, 1996). With their organizational inertia, they are unresponsive to external institutional change (Hannan \& Freeman, 1984; Shimizu \& Hitt, 2005) and unmotivated or unable to adapt new age technological innovations, despite having enough financial resources in hand.

On the contrary, most of these resources and capabilities are not readily available to younger eMNCs as they began in an environment characterized by pro-market reforms and greater competition. Hence, for the younger eMNCs, ICT come across as a lucrative option to create that unique sustainable competitive advantage as they can be implemented relatively faster. These new-age firms looked to invest more in ICT technologies driven by the new opportunities opening in e-commerce and the ICT arena which were deemed lucrative for these start-ups as they entailed minimal investment as compared to the traditional manufacturing sector firms (McKendrick, 2016). Younger eMNCs, with their greater flexibility and adaptability should invest more in these new and emerging ICT technologies to compete with their matured established peers. Several researchers (Goode \& Stevens, 
2000; Hollenstein, 2004) already demonstrated that small and medium-sized enterprises are more flexible and capable to adapt ICT more quickly than larger companies can.

Hypothesis One: Younger eMNCs invest more in ICT, compared to their older peers.

\section{The Moderating Role of Business Group Affiliation}

Business groups are a prominent organizational form in emerging markets such as India (Khanna \& Rivkin, 2001). BGs have been defined as " [...] a collection of legally independent firms that are linked by multiple ties, including ownership, economic means (such as inter-firm transactions), and/or social relations (family, kinship, friendship) through which they coordinate to achieve mutual objectives" (Yiu et al., 2007, p. 1553). In India 45 of the 50 largest corporations are BGs (Ramachandran, Manikandan, $\&$ Pant, 2013). From an institutional theory perspective, by providing an internal market for capital, managerial talent, intermediate products, information, and other important strategic factors, BGs are a solution to factor market underdevelopment, high information asymmetries, poor contract enforcement, and imperfect regulatory structures in emerging economies (Khanna \& Palepu, 1997; Yiu et al., 2007).

The BG affiliated firms, benefit from their quasi-internal capital markets, which ensures an easy access to patient capital (Khanna \& Rivkin, 2001). Apart from financial capital, the BG structure is also able to provide access to internal factor markets and supply technology at attractive rates, which can help the new venture to sustain and grow. In addition, BG affiliated firms can take benefits of relational capital that BGs invest in suppliers, distributors, government agencies. These firms gain competitive advantage through that relational capital, learning of BG affiliated firms and shared experiences of managers. BGs, by virtue of investing in an umbrella brand name and staking the group's reputation for fair dealing (Khanna \& Rivkin, 2001), create better credibility and consumer confidence for their products. On the contrary, such resources are not readily available to the independent firms. Hence, they need to make additional efforts to achieve sustainable competitive advantage. Investing in new and emerging ICT technologies can help these companies to increase their potential for competitive advantage by enabling them to perform primary and support activities either at lesser cost or in a way that leads to differentiation and a premium price (Porter and Millar, 1985). Previous researches (Kowtha \& Choon, 2001; Hwang, Kua, Yen, \& Cheng, 2004) had already argued that firms facing tough competitive environment are more likely to invest in ICT, as a way of strengthening its performance and ensuring its survival, than a firm operating in a more sheltered environment.

In conclusion, BG affiliated eMNCs benefit from easy access to group resources including capital, technology, human resources and complementary products and services and hence are better placed than independent firms in terms of their survivability (Gaur, Kumar, \& Singh, 2014). As a result, they do not face an urgent need to invest aggressively in new and emerging ICT technologies, as standalone eMNCs do. Thus, the authors expect that non-BG independent eMNCs tend to invest more on ICT based emerging technologies to create a competitive edge over their BG-affiliated peers.

Hypothesis Two: BG affiliation has a negative moderating effect on the relationship between eMNC age and ICT investment.

\section{The Moderating Role of Foreign Institutional Owners}

The pro-market reforms initiated by the Government of India in 1991, not only helped to bring in foreign direct investment (FDI) or aMNCs into the Indian market but it also helped to bring in the foreign institutional investors (FII) to invest in the capital markets of the country (Ross, 2019; Nagaraj, 2013; Wadhva, 2000). FIIs based in developed market economies may provide eMNCs the access to a global pool of financial resources (Taylor, 1990). Further, foreign ownership is found to facilitate technology transfer (Chibber and Majumdar, 1999), which can particularly benefit the eMNCs in learning and adopting new and emerging ICT. Based on their global investment experiences, FIIs 
can provide eMNCs with access to strategic expertise and knowledge to help them invest in newer ICT technologies. They can provide access to extensive networks of business partners and external professionals for ICT implementation. These would position domestic firms to benefit from the spill over of technological knowledge. As networking heightens awareness of innovation and increases the likelihood of its adoption (Abrahamson and Rosenkopf, 1997), it is expected that FIIs will help eMNCs to be aware about new developments in ICT arena and adopt them. Researchers (Dedrick \& Kraemer, 2005) had already demonstrated that Taiwanese electronics firms bridge their knowledge gap in using IT by learning from foreign investors. Hence, firms with FII investments are likely to not only have higher ICT investments, but also witness a weaker effect of age on ICT investments.

Hypothesis Three: Foreign institutional ownership has a positive moderating effect on the relationship between eMNC age and ICT investment.

\section{Sample and Data}

India is an appropriate setting for this study as many new firms came in existence in last two decades, especially after the deregulation and liberalization of Indian economy in 1991. Today India is the second largest home to eMNCs (BCG, 2013) and it has the world's second largest internet user base (The Economic Times, 2019). The study uses secondary data obtained from the BSE 500 index and Prowess database to test our hypotheses. These databases have been used in prior research to examine Indian firms' strategy and their performance outcomes (Elango and Pattnaik, 2007; Ray, Mondal, \& Ramachandran, 2018). While BSE 500 index provided data on large Indian firms based on their market capitalization, Prowess provided various firm-level financial information as well as information on their ownership patterns. As this study is interested in private Indian eMNCs, all the multinational subsidiaries and public sectors firms were removed from the sample. Similarly, financial services firms were removed due to their different accounting practices. Finally, the authors were left with 394 eMNCs, which constitute the primary sample set.

\section{Variables}

The study's outcome variable is ICT Investment Intensity. Following prior studies (Ho et al., 2011; Navyashree and Bhat, 2014) ICT investments was measured as the total of net expenses towards software, net investment on computers and IT systems, communication equipment, software charges and IT enabled service charges. Since relatively larger firms have more resources to invest on ICT, the ICT Investment Intensity variable has been normalized for firm size by considering it as a percentage over total sales of that year.

Our main independent variable is Firm Age. Age of the firm represents the length of time that the firm has been in the market. It is operationalized as the log of the years a particular firm had been in

Figure 1. Conceptual model

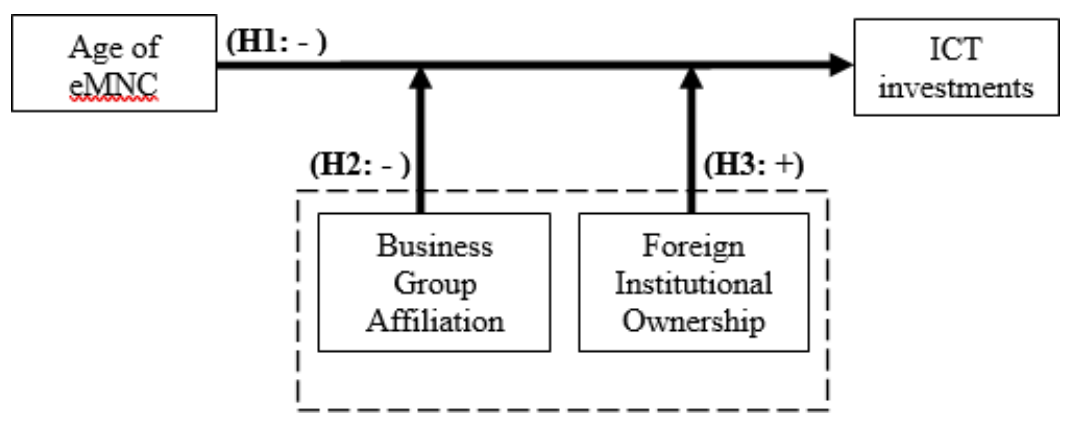


existence. We used two moderating variables in this study: BG Affiliation and Foreign Institutional Ownership. Our BG affiliation variable is a dummy variable that took the value of 1 if our sampled firms belonged to a BG, and 0 if not. This measurement is consistent with numerous studies in the existing literature (Elango \& Pattnaik, 2007; Khanna \& Rivkin, 2001). Foreign Institutional Ownership was operationalized as the percentage of common shareholdings by foreign institutional investors, including foreign venture capitalists (Humphery-Jenner \& Suchard, 2013; Ray et al., 2018).

Several variables were used to control for possible confounding effects on the study's findings. First, firm size-measured as the natural logarithm of total sales-was used to control for the size effects on firms' ICT investments. Second, firm internationalization using OFDI intensity (calculated as ratio of foreign investments to total investments) was used to control for its influence on ICT adoption strategy. Since available financial slack can influence firms' investment in ICT technologies, current ratio and debt to equity ratio were included as control variables. The next two controls, firm financial resources in terms of the liquid assets that are possessed by a firm in the form of cash, bank balances, and marketable securities, normalized with respect to total sales and firm non-financial resources i.e. the total annual sales and general administrative expenses as percentage of sales were controlled for as they are known to facilitate firms' ICT adoption. Further, we controlled for $R \& D$ intensity, which was measured as the annual research and development expenses as percentage of sales. GDP growth rate was included in the model to control for the economic development of the country. Asset Intensity or the ratio of gross fixed assets to net sales was added as a control as asset intensive firms may have a different approach to ICT investments as compared to asset light firms. In addition to the above nine variables, another three controls were included. Prior performance was included as a control since it has the potential to influence firms' investment strategies. We also controlled for ICT infrastructure (measured through broadband users as a percentage of total population), as it plays a substantial role in catalysing economic growth, especially in today's era of internet and mobile connectivity (Lin \& Wu, 2013). In addition, pro-market reform was included to control for the influence of government-initiated regulatory changes over the years. Such reforms are aimed to facilitate 'ease of doing business' in a country (Dau, 2012). This variable was measured using the International Monetary Fund's structural reforms index (Sahay \& Goyal, 2006). Finally, year dummies and industry dummies (at two-digit NIC level) were added to control for the impact of Indian macroeconomic conditions and industry effects respectively.

\section{Results}

Table 1 reports the descriptive statistics for the variables of interest. Table 2 reports the panel regression results of the main effect of the firm age as well as the conditional effect of ownership and competition on ICT investments. The models are arranged incrementally, with the main baseline specification followed by the model with interaction variables added. The various fit parameters, like the overall chi-squared value, show that the model increasingly fits the data better.

Given the nature of our variables generalized least square (GLS) models was used for panel data, with correction for heteroscedasticity and autocorrelation. In all our models, the dependent variables (from 2010 to 2019) are regressed against the independent and control variables (from 2009 to 2018) to ensure that the direction of causality is from firm age to ICT investments and not the reverse. This study did not consider fixed effect models since they would automatically drop the time invariant measures used in this study (e.g., BG, industry and time dummies). The authors confirmed this by running the Hausman test which suggested that the random effects models are adequate for our analysis. The various assumptions of regression analysis such as normality of residuals, heteroscedasticity, and collinearity diagnostics were verified. All VIF values were less than 3.5 indicating that multicollinearity is not a concern in our analysis.

As per hypothesis 1 , older firms, on average are more likely to invest lesser on ICT. 
Table 1. Descriptive statistics and correlations

\begin{tabular}{|c|c|c|c|c|c|c|c|c|c|c|c|c|c|c|c|c|}
\hline & 1 & 2 & 3 & 4 & 5 & 6 & 7 & 8 & 9 & 10 & 11 & 12 & 13 & 14 & 15 & 16 \\
\hline 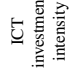 & 1 & & & & & & & & & & & & & & & \\
\hline 貝总 & $-0.20^{*}$ & 1 & & & & & & & & & & & & & & \\
\hline 迎莺 & 0.01 & $-0.03^{*}$ & 1 & & & & & & & & & & & & & \\
\hline 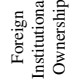 & $0.09 *$ & $0.16^{*}$ & $0.20^{*}$ & 1 & & & & & & & & & & & & \\
\hline 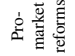 & -0.01 & $0.03 *$ & 0.00 & $0.04^{*}$ & 1 & & & & & & & & & & & \\
\hline 貝总 & $-0.21 *$ & $0.34^{*}$ & $0.06^{*}$ & $0.31 *$ & $0.05 *$ & 1 & & & & & & & & & & \\
\hline 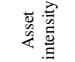 & $0.30^{*}$ & $-0.11 *$ & $0.08^{*}$ & 0.02 & -0.01 & $-0.32^{*}$ & 1 & & & & & & & & & \\
\hline 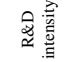 & -0.02 & $0.03^{*}$ & $0.04 *$ & $0.07 *$ & 0.00 & 0.00 & -0.00 & 1 & & & & & & & & \\
\hline 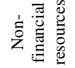 & 0.02 & $0.09 *$ & $0.10^{*}$ & $0.03^{*}$ & -0.00 & $-0.06^{*}$ & 0.01 & $0.09^{*}$ & 1 & & & & & & & \\
\hline 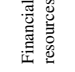 & $0.14 *$ & $0.07 *$ & $-0.17^{*}$ & -0.02 & $0.07 *$ & $-0.06^{*}$ & $0.32 *$ & 0.02 & $-0.04 *$ & 1 & & & & & & \\
\hline 疍 & $0.17 *$ & $-0.03^{*}$ & $-0.05^{*}$ & $0.06^{*}$ & -0.00 & $-0.11^{*}$ & 0.02 & 0.00 & $-0.05^{*}$ & $0.27^{*}$ & 1 & & & & & \\
\hline 总 & $-0.07 *$ & $-0.13^{*}$ & $0.05^{*}$ & $-0.14^{*}$ & -0.00 & -0.01 & $0.05^{*}$ & $-0.07 *$ & $-0.05^{*}$ & $-0.11^{*}$ & $-0.29 *$ & 1 & & & & \\
\hline 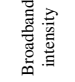 & -0.02 & $0.16^{*}$ & 0.00 & $0.21^{*}$ & $0.33^{*}$ & $0.23^{*}$ & 0.00 & $0.04 *$ & $-0.05^{*}$ & $0.13^{*}$ & 0.02 & $-0.11 *$ & 1 & & & \\
\hline 命言营 & 0.01 & $-0.07 *$ & 0.00 & $-0.09 *$ & $-0.35^{*}$ & $-0.11^{*}$ & 0.00 & -0.02 & $0.03^{*}$ & $-0.15^{*}$ & -0.00 & $0.06^{*}$ & $-0.55^{*}$ & 1 & & \\
\hline 容离 & $0.07 *$ & $0.06^{*}$ & $0.14 *$ & $0.20^{*}$ & $0.05^{*}$ & $0.04 *$ & $0.06^{*}$ & $0.14^{*}$ & -0.01 & $-0.03^{*}$ & 0.00 & $-0.03^{*}$ & $0.18^{*}$ & $-0.12 *$ & 1 & \\
\hline 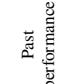 & $0.03 *$ & $0.07 *$ & $-0.13^{*}$ & $0.07^{*}$ & -0.01 & $0.07 *$ & $-0.25^{*}$ & -0.01 & $0.11^{*}$ & 0.01 & $0.23^{*}$ & $-0.37 *$ & -0.02 & 0.02 & $-0.08^{*}$ & 1 \\
\hline$\sum_{\overline{\mathrm{E}}}^{\mathrm{E}}$ & 0.01 & 35.96 & 0.52 & 10.06 & 54.64 & 9.97 & 2.09 & 0.01 & 0.07 & 0.11 & 1.18 & 0.63 & 1.18 & 7.31 & 0.03 & 12.95 \\
\hline 离 & 0.02 & 24.11 & 0.50 & 10.31 & 0.93 & 1.54 & 3.47 & 0.02 & 0.08 & 0.25 & 1.17 & 0.99 & 0.23 & 1.26 & 0.07 & 13.20 \\
\hline
\end{tabular}

Note: $n=3,756$. Reported means and standard deviations are before standardization.

${ }^{*} p<0.05$

a dummy variable

b Log transformed variable 
Model 1 of Table 2 shows that, in predicting ICT investments, the coefficient of age is negative and statistically significant, i.e., (Firm age, $\beta=-0.026$; $p<0.001$ ). Hence, as compared to younger firms, older firms invest a lesser portion of their sales revenue on ICT. Thus, hypothesis 1 is supported.

As per hypothesis 2, BG affiliation is likely to have a negative impact on firm age in predicting ICT investments. The coefficient for the interaction effect in Model 3 is positive and statistically significant, i.e., (BG affiliation X Firm age, $\beta=0.014 ; \mathrm{p}<0.05$ ). It indicates that BG affiliation has a moderating influence in such a way that the negative influence of firm age on ICT investment becomes stronger in BG affiliated firms. To provide further insights into the moderating effects, two plots that compare the interaction effects of BG affiliation and firm age and that of non-BG, independent firms and firm age were created. As shown in Figure 2, the line trend indicates that the negative firm age-ICT investment relationship becomes stronger when the firm is affiliated to a BG network, as for a given level of firm age, ICT investment is lower for BG affiliated firms. This result lends support to Hypothesis 2. The study further finds that BG firms ICT investment declines at a lower rate over time as compared to non-BG firms. Thus, this study argues that as the BG affiliated firm matures over time, it gets highly integrated within the BG network structure. The complex coordination problems

Table 2. Regression Analysis

\begin{tabular}{|c|c|c|c|c|c|c|c|c|c|c|}
\hline \multirow{3}{*}{ Pro-market reforms } & \multirow{2}{*}{\multicolumn{2}{|c|}{ 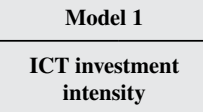 }} & \multirow{2}{*}{\multicolumn{2}{|c|}{$\begin{array}{c}\text { Model 2 } \\
\begin{array}{l}\text { ICT investment } \\
\text { intensity }\end{array}\end{array}$}} & \multirow{2}{*}{\multicolumn{2}{|c|}{ 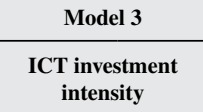 }} & \multirow{2}{*}{\multicolumn{2}{|c|}{ 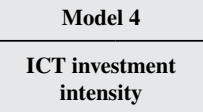 }} & \multirow{2}{*}{\multicolumn{2}{|c|}{$\begin{array}{c}\text { Model 5 } \\
\begin{array}{l}\text { ICT investment } \\
\text { intensity }\end{array}\end{array}$}} \\
\hline & & & & & & & & & & \\
\hline & -0.002 & $(0.004)$ & -0.003 & $(0.004)$ & -0.003 & $(0.004)$ & -0.002 & $(0.004)$ & -0.003 & $(0.003)$ \\
\hline Firm size ${ }^{b}$ & $-0.047 * * *$ & $(0.004)$ & $-0.046 * * *$ & (0.004) & $-0.045^{* * *}$ & $(0.005)$ & $-0.048 * * *$ & $(0.005)$ & $-0.075^{* * *}$ & $(0.005)$ \\
\hline Asset intensity & $0.036^{* * *}$ & $(0.009)$ & $0.038 * * *$ & $(0.009)$ & $0.037^{* * *}$ & $(0.009)$ & $0.033^{* * *}$ & $(0.009)$ & $0.045^{* * *}$ & $(0.011)$ \\
\hline$R \& D$ intensity & 0.007 & $(0.004)$ & $0.008 *$ & $(0.004)$ & $0.008^{*}$ & $(0.004)$ & $0.007 *$ & (0.004) & 0.006 & $(0.004)$ \\
\hline Non-financial resources & $0.007 *$ & $(0.004)$ & $0.008 * *$ & $(0.004)$ & $0.009^{* *}$ & $(0.004)$ & $0.007^{*}$ & (0.004) & $0.021 * * *$ & $(0.003)$ \\
\hline Financial resources & $-0.007 *$ & $(0.004)$ & $-0.007 *$ & $(0.004)$ & $-0.007 *$ & $(0.004)$ & -0.006 & $(0.004)$ & -0.002 & $(0.004)$ \\
\hline Liquidity & 0.001 & $(0.003)$ & -0.000 & $(0.003)$ & 0.000 & $(0.003)$ & -0.001 & $(0.004)$ & 0.000 & $(0.003)$ \\
\hline Leverage & -0.004 & $(0.003)$ & -0.003 & $(0.003)$ & -0.004 & $(0.003)$ & -0.003 & $(0.003)$ & $-0.009 * * *$ & $(0.003)$ \\
\hline Broadband intensity & 0.079 & $(0.063)$ & 0.082 & $(0.061)$ & 0.079 & $(0.063)$ & 0.078 & $(0.063)$ & $0.097 *$ & $(0.054)$ \\
\hline GDP growth rate & 0.037 & $(0.036)$ & 0.038 & $(0.035)$ & 0.037 & $(0.036)$ & 0.035 & $(0.036)$ & 0.049 & $(0.031)$ \\
\hline OFDI intensity & 0.005 & $(0.003)$ & 0.005 & $(0.003)$ & 0.005 & $(0.003)$ & 0.004 & $(0.004)$ & $0.006 * *$ & $(0.003)$ \\
\hline Past performance & $0.007 * *$ & $(0.003)$ & $0.007 *$ & $(0.003)$ & $0.006^{*}$ & $(0.003)$ & $0.007^{* *}$ & $(0.003)$ & $0.007 * *$ & $(0.003)$ \\
\hline Firm age & $-0.026^{* * * *}$ & $(0.005)$ & $-0.026 * * *$ & $(0.005)$ & $-0.025 * * *$ & $(0.006)$ & $-0.024 * * *$ & $(0.005)$ & $-0.043 * * *$ & $(0.005)$ \\
\hline BG-affiliated ${ }^{\text {a }}$ & & & $-0.008^{* *}$ & $(0.004)$ & $-0.008 * *$ & $(0.004)$ & & & & \\
\hline $\begin{array}{l}\text { BG-affiliation a } X \text { Firm } \\
\text { age }\end{array}$ & & & & & $0.014 * *$ & $(0.006)$ & & & & \\
\hline $\begin{array}{l}\text { Foreign institutional } \\
\text { ownership }\end{array}$ & & & & & & & $0.008^{* *}$ & $(0.004)$ & $0.016^{* * *}$ & $(0.003)$ \\
\hline $\begin{array}{l}\text { Foreign institutional } \\
\text { ownership X Firm age }\end{array}$ & & & & & & & & & $0.009 *$ & $(0.005)$ \\
\hline Constant & -0.237 *** & $(0.050)$ & $-0.245^{* * *}$ & $(0.048)$ & $-0.246^{* * *}$ & $(0.049)$ & $-0.244 * * *$ & $(0.049)$ & $-0.206^{* * *}$ & $(0.043)$ \\
\hline chi-squared & 370.375 & & 365.552 & & 355.081 & & 343.487 & & 711. & \\
\hline Nos of observations & 3756 & & 3756 & & 3756 & & 3756 & & 37 & \\
\hline
\end{tabular}

Note: This table reports the results of random effects panel regression with robust standard errors in parenthesis. Standardized regression coefficients are reported. All models include industry dummies at two-digit NICs as well as time dummies, which are suppressed for parsimony. Significance level (twotailed): * for $p<0.10 ;{ }^{* *}$ for $p<0.05 ;{ }^{* * *}$ for $p<0.001$.

a dummy variable

b Log transformed variable 


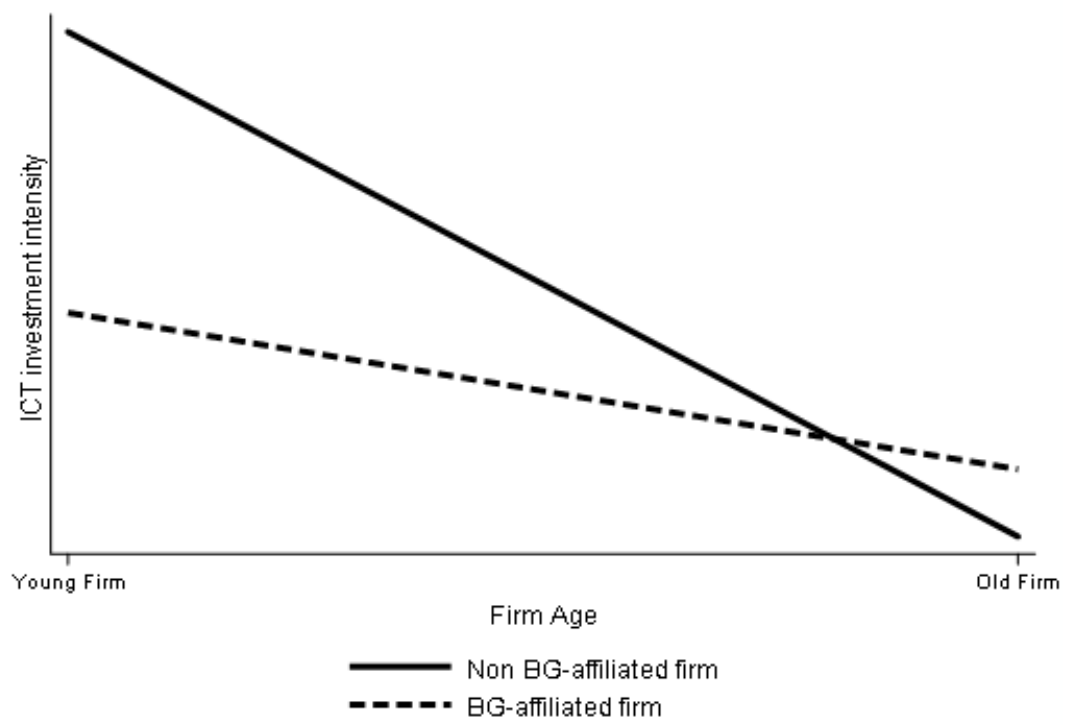

and a greater need for information movement, makes them more likely to use ICT-related tools. For them, the need to navigate within the bureaucratic structure of BG network makes some investment on ICT technologies an imperative, which is not the case for their older independent peers.

As per hypothesis 3, Foreign institutional ownership is likely to have a positive effect on firm age - ICT investments relationship. Model 5 of Table 2 shows that, the interaction of Firm Age and Foreign institutional ownership is positive and statistically significant, i.e., (Foreign institutional ownership $\mathrm{X}$ Firm Age, $\beta=0.009 ; \mathrm{p}<0.10$ ). A plot as depicted in Figure 3 is provided to interpret the result better. The line trend indicates that negative firm age-ICT investment relationship becomes weaker when eMNCs have large foreign institutional ownership. In other words, Foreign institutional owners force eMNCs to have higher ICT investments and the investments declines at a lower rate over time as compared to firms with lower foreign institutional ownership. Thus, hypothesis 3 is also supported.

\section{DISCUSSION}

The rise of eMNCs, especially from China and India have gained tremendous scholarly interest in recent years (Athreye \& Kapur, 2009; Gubbi, Aulakh, Ray, Sarkar, \& Chittoor, 2010). Of the Fortune Global 500 ranking, eMNCs based in emerging markets accounted for 26\% in 2013 and the percentage is predicted to grow up to 45 percent by 2025 (CNBC News, 2013). The ICT capabilities of some of these firms has also been astounding. Rapid advances in IT infrastructure in their home economies and global connectivity have allowed the eMNCs to advance even though they missed the earlier industrial revolutions (Freidman, 2005). Our paper attempts to better understand the factors that have helped the eMNCs to catch up to the capability of the aMNCs as far as ICT is concerned.Our study adds to the information systems literature on barriers to ICT adoption (Bugamelli \& Pagano, 2004; Dubelaar et al., 2005; Qarri, Ilia, \& Bazini, 2011) by demonstrating that eMNCs' institutional embeddedness in the emerging markets, measured as firm age, acts as a major impediment to investments in new and emerging ICT technologies. As eMNCs grows older and become path-dependent in their business approach, the amount of investment in ICT reduces drastically. Additionally, the results in this study tend to point that with age inertia tends to set into the organization (Dawn Kelly \& Amburgey, 1991; 


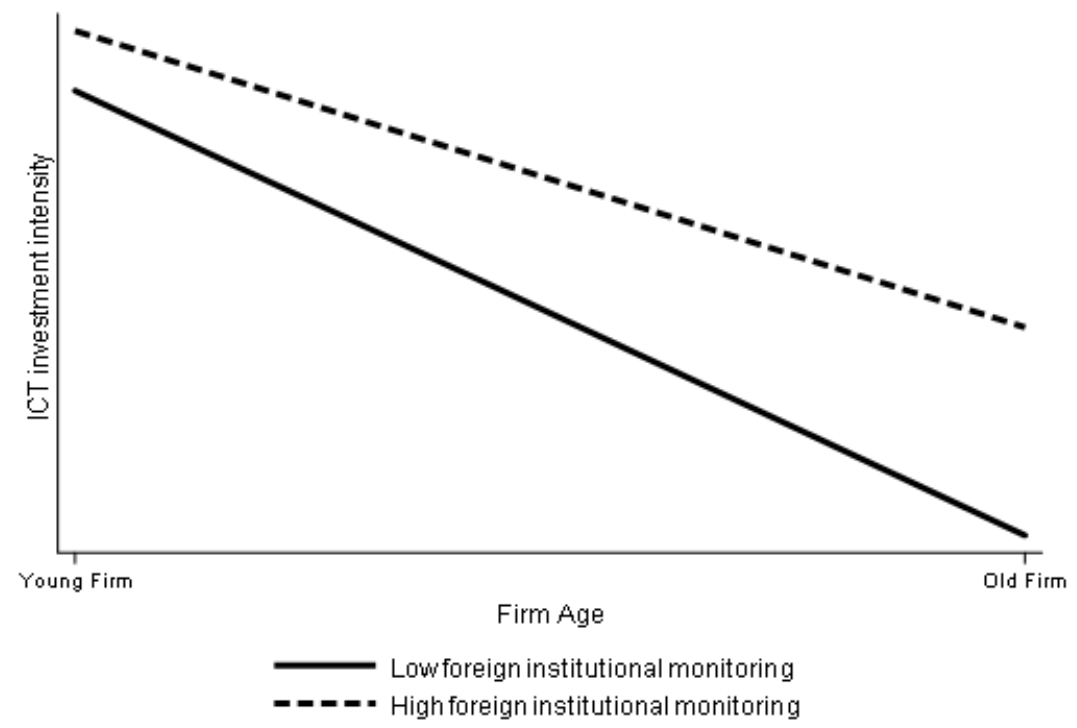

Miller \& Chen, 1994) and it becomes difficult to implement change. This finding may seem somewhat counterintuitive, especially from a traditional lens, in which more resources are associated positively with ICT investments; as younger eMNCs are typically less resource munificent than older and established eMNCs. The study argues for younger eMNCs, lesser legacy resource is an advantage per se, they are nimbler and more adaptable to technological changes than their older peers. Their search for 'new' sources of competitive advantages, beyond the 'traditional' sources of competitive advantage in emerging markets (Khanna \& Rivkin, 2001; Gubbi, et al., 2010) motivate them to invest more in emerging ICT technologies. In other words, eMNCs' home country factors significantly shape their ICT investment strategies.

The study further finds that ownership plays a key role in managing the negative effects of institutional embeddedness on ICT investments. Business groups are an important institutional feature in emerging markets. To the best of our knowledge, no studies analyze the effects of BG affiliation, on the ICT investment strategy of eMNCs. Overall, the findings suggest a negative impact; but a deeper analysis shows that this negative impact is especially prevalent among younger firms than older ones. In other words, as BG affiliation provide significant advantages to affiliated firms (Khanna \& Rivkin, 2001; Elango \& Pattnaik, 2007), such as those resulting from cheaper access to patient capital or the reputational benefits,

their affiliated younger firms do not sense a strong urgency to invest in risky ICT technologies. As non-BG independent firms do not possess such ownership advantages, they end up showing a higher investment on ICT technologies. With time, however, the BG-affiliated firms do not reduce their ICT investments at the same rate as the non-affiliated peers. They gain the ICT capabilities to integrate themselves within the bureaucratic network structure in the group. Similarly, for eMNC firms with foreign institutional holdings, the improvement in governance and awareness about technological advancements ensure higher than average investment in ICT. These findings also clarify that in a context marked by pro-market reforms, multiple forces are simultaneously in action in determining eMNCs adoption to new and emerging ICT technologies. 


\section{Policy Implications}

Many emerging markets carried out impressive structural reforms, by reducing the government restrictions and regulations on economic relationships and improving the governance mechanisms, in the last two decades. One of the effects of these pro-market reforms, has been the increase in the competitive pressures acting on domestic firms specially from aMNCs (Saikia, 1997). It provided opportunities to the aMNCs to enter these markets, through technical and or financial collaborations (Kale \& Anand, 2006; Maryam \& Mittal, 2020). Thus, an increase in competition and the simultaneous explosion of new opportunities due to pro-market reforms helped to increase dynamism and complexity in the task environment for the eMNCs (Boyd \& Gove, 2006). Our study highlights that eMNCs in their inception years have the highest potential to implement ICT in their business models. Hence, policy makers in emerging economies must support new ventures and entrepreneurs with technological platforms and infrastructure such that they may sustain their investment into maturity of the firm. Furthermore, this study demonstrates that although age has a negative impact on ICT investments, it is greater for firms that do not have ownership advantages.

Hence, policy makers may think of giving targeted policy sops to such firms so that their reduction in ICT investment over time are minimized.

\section{Limitations and Future Research Agenda}

The following limitations of the study should be noted while interpreting the results. First, this study is only a beginning of the examination of a largely underexplored issue: relevance of organizational inertia and institutional embeddedness on ICT investments. Firm age, albeit convenient, is a crude proxy for that. It would be worthwhile to explore the process of organizational inertia to delineate the mechanisms through which ICT investments drop with firm age and how owners may attenuate or exuberate the investments in new and emerging ICT technologies. Second, this study employs a sample of Indian firms only, and hence, the authors cannot rule out the possibility of countryspecific nature of the findings. Third, this study only investigates the contingent effect of ownership and age on ICT investments and cannot claim to account for all the other factors that may affect ICT investments. The insights generated from this India based study has ramifications for other emerging as well as developed nations. Hence, more empirical studies to test the same models in other emerging economies with multi-country samples and using more fine-grained measures would contribute to the generalizability of the findings. Moreover, a primary exploratory research may be carried out to unearth other major factors that might affect ICT investment.

\section{CONCLUSION}

In conclusion, the purpose of this study was to shed further light on the eMNCs' ICT adoption strategy in today's digital era. As eMNCs are increasingly becoming a formidable force in international competition, it is important to understand how these firms are embracing the cutting-edge ICT technologies in their business operations. Notwithstanding several limitations of our research, our study revealed how some of the organizational and structural factors shape eMNCs' ICT adoption strategies, and we have covered significant theoretical and empirical ground. We hope that our effort will inspire more research on eMNCs and their competition with the aMNCs in the digital era by leveraging the contextual peculiarities of emerging economies to enrich the information studies literature and practice. 


\section{REFERENCES}

Abrahamson, E., \& Rosenkopf, L. (1997). Social Network Effects on the Extent of Innovation Diffusion: A Computer Simulation. Organization Science, 8(3), 289-309. doi:10.1287/orsc.8.3.289

Agnihotri, V. (2019). Year in Search - India: Insights for brands. Retrieved from Google website: https://www. thinkwithgoogle.com/intl/en-apac/ad-channel/search/year-in-search-india-insights/

Athreye, S., \& Kapur, S. (2009). Introduction: The internationalization of Chinese and Indian firms - Trends, motivations and strategy. Industrial and Corporate Change, 18(2), 209-221. doi:10.1093/icc/dtp007

Autio, E., Sapienza, H. J., \& Almeida, J. G. (2000). Effects of age at entry, knowledge intensity, and imitability on international growth. Academy of Management Journal, 43, 909-924.

Barkema, H., \& Vermeulen, F. (1998). International expansion through start-up or acquistion: A learning perspective. Academy of Management Journal, 41, 7-26.

Beerepoot, N., \& Roodheuvel, I. (2016). Internationalization strategies of emerging market-based multinationals: Integration of Indian ICT-ITES companies on the Dutch service outsourcing market. European Planning Studies, 24(7), 1374-1391. doi:10.1080/09654313.2016.1170107

Boyd, B. K., \& Gove, S. (2006). Managerial constraint: The intersection between organizational task environment and discretion. In D. J. Ketchen Jr \& D. D. Bergh (Eds.), Research Methodolgy in Strategy and Management (Vol. 3, pp. 57-96). Elsevier. doi:10.1016/S1479-8387(06)03005-0

Bugamelli, M., \& Pagano, P. (2004). Barriers to investment in ICT. Applied Economics, 36(20), 2275-2286. doi:10.1080/0003684042000270031

Burgelman, R. A. (2002). Strategy as Vector and the Inertia of Coevolutionary Lock-in. Administrative Science Quarterly, 47(2), 325-357. doi:10.2307/3094808

Carney, M., Gedajlovic, E. R., Heugens, P. P., Van Essen, M., \& Van Oosterhout, J. (2011). Business group affiliation, performance, context, and strategy: A meta-analysis. Academy of Management Journal, 54(3), 437-460. doi:10.5465/amj.2011.61967812

Chacar, A. S., \& Vissa, B. (2005). Are emerging economies less efficient? Performance persistence and the impact of business group affiliation. Strategic Management Journal, 26(10), 933-946. doi:10.1002/smj.478

Chari, M. D. R., \& Dixit, J. (2015). Business groups and entrepreneurship in developing countries after reforms. Journal of Business Research, 68(6), 1359-1366. doi:10.1016/j.jbusres.2014.12.006

Chhibber, P. K., \& Majumdar, S. K. (1999). Foreign Ownership and Profitability: Property Rights, Control, and the Performance of Firms in Indian Industry. The Journal of Law \& Economics, 42(1), 209-238. doi:10.1086/467423

Chittoor, R., Sarkar, M., Ray, S., \& Aulakh, P. S. (2009). Third-world copycats to emerging multinationals: Institutional changes and organizational transformation in the Indian pharmaceutical industry. Organization Science, 20(1), 187-205. doi:10.1287/orsc.1080.0377

Contractor, F. J. (2013). "Punching above their weight": The sources of competitive advantage for emerging market multinationals. International Journal of Emerging Markets, 8, 304-328. doi:10.1108/IJoEM-06-2013-0102

Dau, L. A. (2012). Pro-market reforms and developing country multinational corporations. Global Strategy Journal, 2(3), 262-276. doi:10.1111/j.2042-5805.2012.01033.x

Dau, L. A. (2013). Learning across geographic space: Pro-market reforms, multinationalization strategy, and profitability. Journal of International Business Studies, 44(3), 235-262. doi:10.1057/jibs.2013.5

Dedrick, J., \& Kraemer, K. L. (2005). The impacts of IT on firm and industry structures the personal computer industry. California Management Review, 47(3), 122-142. doi:10.2307/41166309

Demirkan, I., Yang, Q., \& Jiang, C. X. (2019). Corporate entrepreneurship of emerging market firms: current research and future directions. New England Journal of Entrepreneurship.

Dimaggio, P. J., \& Powell, W. W. (1983). The iron cage revisited: Institutional isomorphism and collective rationality in organizational fields. American Sociological Review, 48(2), 147-160. doi:10.2307/2095101 
Dohse, D., Hassink, R., \& Klaerding, C. (2012). Emerging multinationals, international knowledge flows and economic geography: A research agenda (No. 1776). Kiel.

Dubelaar, C., Sohal, A., \& Savic, V. (2005). Benefits, impediments and critical success factors in B2C E-business adoption. Technovation, 25(11), 1251-1262. doi:10.1016/j.technovation.2004.08.004

Elango, B., \& Pattnaik, C. (2007). Building capabilities for international operations through networks : A study of Indian firms. Journal of International Business Studies, 38(4), 541-555. doi:10.1057/palgrave.jibs.8400280

Fabiani, S., Schivardi, F., \& Trento, S. (2005). ICT adoption in Italian manufacturing: Firm level evidence. Industrial and Corporate Change, 14(2), 225-249. doi:10.1093/icc/dth050

Freidman, T. L. (2005). The world is flat. Farrar, Straus and Giroux.

Gaur, A. S., Kumar, V., \& Singh, D. (2014). Institutions, resources, and internationalization of emerging economy firms. Journal of World Business, 49(1), 12-20. doi:10.1016/j.jwb.2013.04.002

George, G., Wiklund, J., \& Zahra, S. A. (2005). Ownership and the Internationalization of Small Firms. Journal of Management, 31(2), 210-233. doi:10.1177/0149206304271760

Goode, S., \& Stevens, K. (2000). An analysis of the business characteristics of adopters and non-adopters of World Wide Web technology. Information Technology and Management, 1(1/2), 129-154. doi:10.1023/A:1019112722593

Gubbi, S. R., Aulakh, P. S., Ray, S., Sarkar, M. B., \& Chittoor, R. (2010). Do international acquisitions by emerging-economy firms create shareholder value? The case of Indian firms. Journal of International Business Studies, 41(3), 397-418. doi:10.1057/jibs.2009.47

Guillén, M. F. (2002). Structural inertia, imitation, and foreign expansion: South Korean firms and business groups in China, 1987-95. Academy of Management Journal, 45(3), 509-525. doi:10.2307/3069378

Hannan, M. T., \& Freeman, J. (1984). Structural inertia and organizational change. American Sociological Review, 49(2), 149-164. doi:10.2307/2095567

Helfat, C. E., \& Peteraf, M. A. (2003). The dynamic resource-based view: Capability lifecycles. Strategic Management Journal, 24(10), 997-1010. doi:10.1002/smj.332

Hillman, A. J., Zardkoohi, A., \& Bierman, L. (1999). Corporate political strategies and firm performance: Indications of firm-specific benefits from personal service in the US government. Strategic Management Journal, 20(1), 67-81. doi:10.1002/(SICI)1097-0266(199901)20:1<67::AID-SMJ22>3.0.CO;2-T

Ho, J. L. Y., Wu, A., \& Xu, S. X. (2011). Corporate Governance and returns on information technology investment: Evidence from an emerging market. Strategic Management Journal, 32(6), 595-623. doi:10.1002/smj.886

Hollenstein, H. (2004). Determinants of the adoption of Information and Communication Technologies (ICT): An empirical analysis based on firm-level data for the Swiss business sector. Structural Change and Economic Dynamics, 15(3), 315-342. doi:10.1016/j.strueco.2004.01.003

Hoskisson, R. E., Eden, L., Lau, C. M., \& Wright, M. (2000). Strategy in emerging economies. Academy of Management Journal, 43, 249-267.

Humphery-Jenner, M., \& Suchard, J. A. (2013). Foreign VCs and venture success: Evidence from China. Journal of Corporate Finance, 21, 16-35. doi:10.1016/j.jcorpfin.2013.01.003

Kale, P., \& Anand, J. (2006). The decline of emerging economy joint ventures. California Management Review, 48(3), 62-77. doi:10.2307/41166350

Kelly, , D., \& Amburgey, T. L. (1991). Organizational inertia and momentum: A dynamic model of strategic change. Academy of Management Journal, 34, 591-612.

Kelly, D., \& Amburgey, T. L. (1991). Organizational Inertia and Momentum: A Dynamic Model of Strategic Change. Academy of Management Journal, 34, 591-612.

Khanna, T., \& Palepu, K. (1997). Why focused strategies may be wrong for emerging markets. Harvard Business Review, 75, 41-51. 
Khanna, T., \& Palepu, K. (2000). The future of business groups in emerging markets: Long-run evidence from Chile. Academy of Management Journal, 43, 268-285.

Khanna, T., \& Rivkin, J. W. (2001). Estimating the performance effects of business groups in emerging markets. Strategic Management Journal, 22(1), 45-74. doi:10.1002/1097-0266(200101)22:1<45::AIDSMJ147>3.0.CO;2-F

Khanna, T., \& Yafeh, Y. (2007). Business Groups in Emerging Markets: Paragons or Parasites? Journal of Economic Literature, 45(2), 331-372. doi:10.1257/jel.45.2.331

Knockaert, M., Spithoven, A., \& Clarysse, B. (2010). The knowledge paradox explored: What is impeding the creation of ICT spin-offs? Technology Analysis and Strategic Management, 22(4), 479-493. doi: $10.1080 / 09537321003714535$

Kohli, R., \& Devaraj, S. (2003). Measuring information technology payoff: A meta-analysis of structural variables in firm-level empirical research. Information Systems Research, 14(2), 14. doi:10.1287/isre.14.2.127.16019

Kowtha, N. R., \& Choon, T. I. (2001). Information \& management determinants of website development: A study of electronic commerce in Singapore. Information \& Management, 39(3), 227-242. doi:10.1016/S03787206(01)00092-1

Lapierre, J., \& Denier, A. (2005). ICT adoption and moderating effects of institutional factors on salesperson's communication effectiveness: A contingency study in high-tech industries. Technovation, 25(8), 909-927. doi:10.1016/j.technovation.2004.01.012

Liang, T.-P., You, J.-J., \& Liu, C.-C. (2010). A resource-based perspective on information technology and firm performance: A meta analysis. Industrial Management \& Data Systems, 110(8), 1138-1158. doi:10.1108/02635571011077807

Lin, M. S., \& Wu, F. S. (2013). Identifying the determinants of broadband adoption by diffusion stage in OECD countries. Telecommunications Policy, 37(4-5), 241-251. doi:10.1016/j.telpol.2012.06.003

Mandavia, M. (2019, September 26). India has second highest number of Internet users after China: Report. Economic Times. https://economictimes.indiatimes.com/tech/internet/india-has-second-highest-number-ofinternet-users-after-china-report/articleshow/71311705.cms

Maryam, J., \& Mittal, A. (2020). Foreign direct investment into BRICS: An empirical analysis. Transnational Corporations Review, 12(1), 1-9. doi:10.1080/19186444.2019.1709400

McKendrick, J. (2016). With Internet Of Things And Big Data, 92\% Of Everything We Do Will Be In The Cloud. Forbes. https://www.forbes.com/sites/joemckendrick/2016/11/13/with-internet-of-things-and-big-data92-of-everything-we-do-will-be-in-the-cloud/\#3df06b304ed5

Melville, N., Kraemer, K., \& Gurbaxani, V. (2004). Review: Information technology and organizational performance: An integrative model of IT business value. Management Information Systems Quarterly, 28(2), 283-322. doi:10.2307/25148636

Miller, D., \& Chen, M. (1994). Sources and consequences of competitive inertia: A study of the US airline industry. Administrative Science Quarterly, 39(1), 1-23. doi:10.2307/2393492

Morgan, A., Colebourne, D., \& Thomas, B. (2006). The development of ICT advisors for SME business: An innovative approach. Technovation, 26(8), 980-987. doi:10.1016/j.technovation.2005.09.001

Nagaraj, R. (2013). India's dream run, 2003-08: Understanding the boom and its aftermath. Economic and Political Weekly, 48, 39-51.

Navyashree, G., \& Bhat, S. (2014). ICT Investments and Growth of Small and Medium Firms: A Study of Food Processing Industry in India. Retrieved from http://www.fgks.in/images/pdf/conf/2016/Navyashree.pdf

Porter, M. E. (2001). Strategy and the internet. Harvard Business Review, (March), 63-78. PMID:11246925

Porter, M. E., \& Miller, V. E. (1985). How information gives you competitive advantage. 10.1002/ijc.2910610124

Qarri, A., Ilia, D., \& Bazini, E. (2011). Barriers of ICT implementation within SMEs in service sector in Albania. Euro Economica, 3, 114-120. 
Ramachandran, J., Manikandan, K. S., \& Pant, A. (2013). Why conglomerates thrive (outside the U.S.). Harvard Business Review, 91, 110-119.

Ray, S., Mondal, A., \& Ramachandran, K. (2018). How does family involvement affect a firm's internationalization? An investigation of Indian family firms. Global Strategy Journal, 8(1), 73-105. doi:10.1002/gsj.1196

Ross, A. G. (2019). Governance infrastructure and FDI flows in developing countries. Transnational Corporations Review, 11(2), 109-119. doi:10.1080/19186444.2019.1640572

Sahay, R., \& Goyal, R. (2006). Volatility and growth in Latin America: An Episodic Approach (No. WP/06/287). Academic Press.

Saikia, T. (1997). Determinants of entry: A study of Indian manufacturing sector. Economic and Political Weekly, 32, 55-58.

Schuler, D. A., Rehbein, K., \& Cramer, R. D. (2002). Pursuing strategic advantage through political means: A multivariate approach. Academy of Management Journal, 45, 659-672.

Shimizu, K., \& Hitt, M. A. (2005). What constrains or facilitates divestitures of formerly acquired firms? The effects of organizational inertia. Journal of Management, 31(1), 50-72. doi:10.1177/0149206304271381

Teece, D. J. (2007). Explicating dynamic capabilities: The nature and microfoundations of (sustainable) enterprise performance. Strategic Management Journal, 28(13), 1319-1350. doi:10.1002/smj.640

Uzzi, B. (1996). The sources and consequences of embeddedness for the economic performance of organizations: The network effect. American Sociological Review, 61(4), 674-698. doi:10.2307/2096399

Vukasovič, T. (2012). Searching for competitive advantage with the brand extension process. Journal of Product and Brand Management, 21(7), 492-498. doi:10.1108/10610421211276231

Wadhva, C. D. (2000). Political economy of post-1991 economic reforms in India. South Asia, 23(sup1), 207-222. doi:10.1080/00856400008723409

Arindam Mondal is an Assistant Professor in Strategic Management Area currently working with XLRI, Jamshedpur, India. He has published his research work in reputed international journals such as, Global Strategy Journal, International Journal of Entrepreneurial Behavior \& Research etc.

Amit B. Chakrabarti is an Assistant Professor at Indian Institute of Management Visakhapatnam, India. He joined academia after completing 8 years of corporate work experience. His research interests are in the areas of international business, public sector management and entrepreneurship. He has published in several peer reviewed international journals, apart from presenting his research work at several international conferences. 